108 THE IMPACT OF MARITAL STATUS ON MORTALITY AND LENGTH OF STAY IN PATIENTS ADMITTED WITH MYOCARDIAL INFARCTION

${ }^{1}$ Rosie M Hayes*, ${ }^{*}$ Paul R Carter, ${ }^{3}$ Nicholas D Gollop, ${ }^{1}$ Jennifer Reynolds, ${ }^{4}$ Hardeep Uppal, ${ }^{5}$ Jaydeep Sarma, ${ }^{6}$ Suresh Chandran, ${ }^{4}$ Rahul Potluri. ${ }^{1}$ University of Birmingham; ${ }^{2}$ Royal Free London, NHS Trust; ${ }^{3}$ The University of East Anglia; ${ }^{4}$ ACALM Study Unit in Collaboration with Aston Medical School; ${ }^{5}$ University Hospital South Manchester; ${ }^{6}$ Department of Acute Medicine, North Western Deanery; *Presenting Author

\subsection{6/heartjnl-2016-309890.108}

Introduction Ischaemic heart disease is the leading cause of mortality worldwide. The development of surgical and percutaneous interventions has improved survival rates, but the influence of sociodemographic factors on outcomes following MI and their potential use as predictors of such outcomes, are increasingly recognised. Conclusive studies show associations between marriage and lower incidences of IHD in addition to better survival prospects for married individuals suffering MI. There is however, a conflicting evidence base and a lack of literature considering the influence of marital status on LOS, which has been observed to be highly variable in MI patients.

Objectives From a large patient database, we aimed to investigate the impact of marital status on the prevalence, LOS and crude mortality of MI patients admitted in Northern England, UK.

Methods We compared marital status variations and associated LOS and mortality data by one way anova and cox regression respectively, using anonymous information on MI patients obtained from hospitals in North England between $1^{\text {st }}$ January 2000 and $31^{\text {st }}$ March 2013. This data was analysed according to the ACALM (Algorithm for Comorbidities, Associations, Length of stay and Mortality) study protocol, which uses

Abstract 108 Table 1 Length of stay and mortality of patients admitted with ACS stratified by marital status

\begin{tabular}{|c|c|c|c|c|c|}
\hline $\begin{array}{l}\text { Marital } \\
\text { Status }\end{array}$ & $\begin{array}{l}\text { Prevalencen } \\
(\%)\end{array}$ & $\begin{array}{l}\text { Mean } \\
\text { LOS } \\
\text { (Days) }\end{array}$ & $\begin{array}{l}\text { Difference in } \\
\text { mean LOS } \\
\text { compared to } \\
\text { single patients } \\
\text { (95\% confidence } \\
\text { intervals) }\end{array}$ & $\begin{array}{l}\text { Crude } \\
\text { mortalityn } \\
(\%)\end{array}$ & $\begin{array}{l}\text { Odds ratio for } \\
\text { mortality } \\
\text { compared to } \\
\text { single patients } \\
\text { (95\% confidence } \\
\text { intervals) }\end{array}$ \\
\hline Single & $\begin{array}{l}2531 \\
(10.0 \%)\end{array}$ & 8.2 & - & $\begin{array}{l}752 \\
(29.7 \%)\end{array}$ & - \\
\hline Married & $\begin{array}{l}11933 \\
(47.2 \%)\end{array}$ & 6.1 & $\begin{array}{l}-2.12 \\
(-1.05,-3.20)^{* * *}\end{array}$ & $\begin{array}{l}4098 \\
(34.3 \%)\end{array}$ & $\begin{array}{l}0.863 \\
(0.798-0.933) \\
* * *\end{array}$ \\
\hline Divorced & $\begin{array}{l}1105 \\
(4.4 \%)\end{array}$ & 6.8 & $\begin{array}{l}-1.38 \\
(-3.14,0.39)\end{array}$ & $\begin{array}{l}378 \\
(34.2 \%)\end{array}$ & $\begin{array}{l}0.994 \\
(0.934-1.058)\end{array}$ \\
\hline Widowed & $\begin{array}{l}4004 \\
(15.8 \%)\end{array}$ & 10.0 & $\begin{array}{l}1.82 \\
(0.58-3.07) * * *\end{array}$ & $\begin{array}{l}2517 \\
(62.9 \%)\end{array}$ & $\begin{array}{l}0.959 \\
(0.947-0.971) \\
* * *\end{array}$ \\
\hline $\begin{array}{l}\text { Common } \\
\text { Law } \\
\text { Living }\end{array}$ & $\begin{array}{l}5 \\
(0.02 \%)\end{array}$ & 7.8 & $\begin{array}{l}-0.39 \\
(-22.34,21.55)\end{array}$ & $\begin{array}{l}0 \\
(0 \%)\end{array}$ & No deaths \\
\hline Unmarried & $\begin{array}{l}5184 \\
(20.5 \%)\end{array}$ & 6.0 & $\begin{array}{l}-2.66 \\
(-3.34,0.96) * * *\end{array}$ & $\begin{array}{l}1830 \\
(35.3 \%)\end{array}$ & $\begin{array}{l}0.973 \\
(0.956-0.991) \text { ** }\end{array}$ \\
\hline Separated & $\begin{array}{l}284 \\
(1.1 \%)\end{array}$ & 10.5 & $\begin{array}{l}2.26 \\
(-0.80,5.33)\end{array}$ & $\begin{array}{l}78 \\
(27.5 \%)\end{array}$ & $\begin{array}{l}0.983 \\
(0.945-1.022)\end{array}$ \\
\hline Unknown & $\begin{array}{l}241 \\
(1.0 \%)\end{array}$ & 7.2 & $\begin{array}{l}-1.00 \\
(-4.31,2.30)\end{array}$ & $\begin{array}{l}0 \\
(0 \%)\end{array}$ & No deaths \\
\hline
\end{tabular}

ICD-10 and OPCS-4 codes to trace patients and demographics. $\mathrm{P}$ values $<0.05$ were taken as statistically significant. Results Amongst 929552 patient admissions recorded during the study period there were 25287 cases involving a new diagnosis of MI. Mean age of MI patients was 66.6 years, $64.2 \%$ of the cohort were male and $80.3 \%$ were Caucasian. $38.2 \%$ of MI patients died and mean LOS was 7.0 days. Crude mortality was highest among widowed patients (62.9\%). Logistic regression accounting for age, sex and gender showed that married (OR 0.863), widowed (OR 0.959 ) and unmarried patients (OR 0.973) had statistically lower mortality rates when compared to single people. LOS was statistically shorter for married patients (2.12 days shorter), and unmarried patients (2.66 days shorter) compared to a mean LOS of 8.2 days recorded amongst single patients. Conversely, mean LOS was 1.82 days longer for widowed patients.

Conclusion Marital status has a clinically important impact on LOS and mortality of MI patients. In particular, single patients show higher mortality rates and longer LOS compared to married patients. It is reasonable to suggest that these results may be due to reduced social support at home and this should be taken into account when considering the holistic care of patients with MI.

\section{MARKED DIFFERENCES IN THE PHARMACODYNAMICS OF MODERN P2Y12 INHIBITORS IN PATIENTS UNDERGOING TREATMENT FOR ST SEGMENT ELEVATION MI (STEMI) AND NON ST SEGMENT ELEVATION MI (NSTEMI)}

${ }^{1}$ Vincent Amoah* ${ }^{*}{ }^{1}$ Nazish Khan, ${ }^{2}$ Andrew Smallwood, ${ }^{2}$ Ben Wrigley, ${ }^{3}$ Joe Martins, ${ }^{2}$ Saib Khogali, ${ }^{2}$ Shahzad Munir, ${ }^{4}$ Nevill Alan, ${ }^{1}$ James Cotton. ${ }^{1}$ The Royal Wolverhampton Hospitals NHS Trust; ${ }^{2}$ The Royal Wolvehampton Hospitals NHS Trust; ${ }^{3}$ The Dudley Group of Hospitals; ${ }^{4}$ University of Wolverhampton; *Presenting Author

\subsection{6/heartjnl-2016-309890.109}

Introduction Current pharmacodynamic (PD) data suggest reduced antiplatelet effect in ST-Elevation myocardial infarction (STEMI) of prasugrel and ticagrelor. We sought to investigate the early PD effect of prasugrel and ticagrelor administered in two patient groups: those admitted with STEMI and a cohort admitted with NSTEMI/unstable angina (UA).

Methods P2Y12 inhibitor naïve patients presenting with STEMI or NSTEMI/UA were assessed for inclusion. All patients provided informed consent. All received aspirin $(300 \mathrm{mg})$ and loading dose of either prasugrel $(60 \mathrm{mg})$ or ticagrelor $(180 \mathrm{mg})$ in a non-randomised fashion. Platelet reactivity was measured using VerifyNow assay at $20 \mathrm{~min}, 1$ and $4 \mathrm{~h}$ post loading. Results are expressed a P2Y12 reaction units (PRU). PRU $\geq 208$ indicates a sub optimal antiplatelet response. PRU over time was tested between groups using 2 way ANOVA, $\mathrm{P}<0.05$ was considered significant.

Results A total of 58 patients were enrolled (30 STEMI, and 28 NSTEMI/UA Table 1).

Results are shown in Fig 1. In the STEMI patients there was little effect of either agent at 20 min post loading (prasugrel PRU $247+48.8$, ticagrelor PRU $256+50.8$ ) with a limited effect at $1 \mathrm{~h}$ and persisting attenuated results at $4 \mathrm{~h}$. In the NSTEMI group however there was a marked and rapid antiplatelet effect of both agents at all time points. Over time there was a significant difference between the effect of both prasugrel $(\mathrm{P}<0.001)$ and ticagrelor $(\mathrm{P}<0.001)$ in STEMI patients vs NSTEMI patients. There was no significant 